\title{
INDLEDNING TIL TEMAET
}

Når vi har valgt at kalde dette emnenummer for »Til kritikken af det daglige liv«, så ved vi godt, at vi hermed ramler lige ind i en mase forskellige diskussioner, som vi faktisk ikke tager op og forholder os til i dette nummer. Når vi alligevel har fundet det rimeligt at anvende denne overskrift over vores arbejder, er det fordi vi mener, at vi har noget at sige - på vores måde - om de problemer, der tages op i de forskellige analyser og kontroverser omkring en begribelse af »dagliglivet «. ${ }^{1}$ Det betyder imidlertid ikke, at vi her fremlægger en færdig teori om lønarbejdernes dagligdag, under de aktuelle samfundsmæssige betingelser, men at vi tager et par skridt i denne retning.

Dagliglivet er det, alle tilsyneladende kender og kan have en mening om. Det er således alle de naturgroede institutioner og rutiner, som blot forudsættes og aldrig problematiseres. Derfor leverer dagligdagen også det stof, som samfundsmæssigt fungerende ideologier bygges af - det »naturlige«, uforanderlige, selvindlysende ...

Dagliglivet er samfundets pseudo-konkrete sammenhænge og som sådan må det altid være udgangspunktet for en marxistisk analyse. For såvidt er der intet andet nyt i marxismens - og vores - principielle interesse $\mathrm{i} \gg$ det daglige liv« end navnet. Det nye ligger snarere i måden at tematisere problemerne på - en måde der er nødvendiggjort af bestemte samfundsmæssige forandringer, som selv må med i undersøgelsen, men også af en politisk begrundet trang hos os selv til at stikke en (teoretisk) kæp i dagliglivets praktiske, evigt rullende hjul.

Kravet om en »fornyelse « af marxismen indgår som en del af de mange forskellige fænomener, der har fået den salgskraftige samletitel »marxismens krise«. For såvidt marxismen altså er i »krise« fordi den ikke på forhånd har analyseret kapitalismens historiske forandringer, henviser denne »krise « kun til marxismens udogmatiske forhold til virkeligheden, og til det - for marxister - selvfølgelige forhold, at virkelighedens forandringer kun kan kritiseres i samme hastighed som de virkelig finder sted. »Krise«

1. De vigtigste retninger i den mere eksplicitte »hverdagslivsdiskussion « omfatter bl.a.: a) en fænomenologisk retning (E. Husserl, A. Schütz, P. Berger/T. Luckmann, o.a.), b) ethnometodologi og symbolsk interaktionisme (E. Goffman, Arbeitsgruppe Bielefelder Soziologen, G.H. Mead, o.a.), c) forskellige marxistiske teorier (H. Lefebvre, K. Kosik, A. Heller, o.a.) d) marxistiske socialisationsteorier (Leithaüser, Volmberg, o.a.).

Helt for sig selv som en af de få, der har fors $\emptyset$ gt at fremstille de historiske udviklingstendenser i arbejderklassens totale livssituation, står Otto Rühle, hvis store 2-bindsværk anmeldes af Finn Dam Rasmussen i dette nummer. 
i denne betydning henviser således til marxismens produktive udvekslingsforhold med samfundet, og til nye, aktuelle, påtrangende arbejdsopgaver, der må tages fat på.

Men den aktuelle »marxismens krise $\ll^{2}$ omfatter også en lang række problemer af mere intern karakter, som er lige så forskellige, som marxismen er splittet i forskellige opfattelser. Og følgelig findes ligeså mange forklaringer på denne krises årsag, samt programmer til dens løsning. Disse spænder fra at se problemet som et spørgsmål, der kan løses med en »ny politik«, et mere mobiliserende program, nye »alternativer«, osv., og til at se det som et spørgsmål om at forlade teori til fordel for historie. Dvs. helt at forlade alle intentioner om, at marxismen har noget at gøre med teori, endsige teoretisk kritik. Disse forklaringsfors $\varnothing$ g og reaktioner er mange og spredte og de skal ikke analyseres her. ${ }^{3}$

Vor interesse $\mathrm{i} »$ marxismens krise « snævert relateret til dette temanummer af Kurasje er som nævnt, at i disse diskussioner findes forsøg på at rejse problemer om sammenhængen mellem den marxistiske teoris udvikling og forandringer i kapitalismens aktuelle udviklingsformer. Der findes altså andre reaktioner på denne krise, end at opgive og forkaste den marxistiske teori som den nødvendige forudsætning for en systematisk samfundskritik, der kan gennembryde de tilsyneladende sammenhænge som kapitalismens reproducerer. I disse diskussioner findes der således også fors $\emptyset \mathrm{g}$ på at fastholde og udvikle de marxistiske kategorier som teoretisk kritik af de reale forhold.

En sådan marxistisk teoriudvikling kan ikke indpasses i de traditionelle borgerlig-videnskabelige verifikationssammenhænge, hvor teori og empiri (eller historie) fundamentalt er adskilt. For at begribe de historisk specifikke former som kapitalforholdets udvikling producerer og reproducerer sig igennem, må teorien samtidig kunne fastholde både sensibiliteten overfor de historiske forandringer og de i deres væsen uændrede træk ved kapitalismens konstituerende forhold. Absoluteres disse to samtidige momenter hver for sig som positioner - og sådan kan man i en vis forstand læse de skiftende positioner i marxismens historie ender man med en konfrontation mellem på den ene side en afskrivning af den marxske $\varnothing$ konomi-kritik som »forældet« overfor en fastholdelse af den som den

2. Det skal heller ikke overses, at forskellige venlige sjæle - der iøvrigt ellers ikke har bekymret sig om marxismens egne problemer - har erklæret den i »krise« stort set siden dens fødsel. Jvnf. f.eks. »Disse kontroverser havde nået et punkt, ved enden af det nittende århundrede, hvor det blev almindeligt at tale om »marxismens krise«, en krise både intellektuelt og politisk, siden den faldt sammen med den revisionistiske bevægelse i det tyske Socialdemokratiske Parti ... »Marxismens krise« tiltrak sig på samme tid, 1898, Sorel's og Masaryk's opmærksomhed.«(Bottomore/Rubel: Karl Marx, Penguin 1965.)

3. Tidsskriftet Kurasje vil i de kommende numre tage denne diskussion op. 
hele og fulde sandhed om det eksisterende samfund på den anden side. Fastholdes begge samtidige momenter ikke, får man en »krise«, som på nogle punkter ligner den danske marxismes aktuelle krise.

Denne nuværende »marxismens krise « omfatter i et vist omfang selvfølgelig også Kurasje og den tradition i den nyere danske marxistiske diskussion som Kurasje ofte identificeres med: »kapitallogik «. ${ }^{4}$ I en artikel i tidsskriftet $»$ Kontext $\ll^{5}$ fors $\varnothing$ ges visse af de begrænsninger der skulle have præget diskussionen i Kurasje karakteriseret. På baggrund af en artikel fra Kurasje nr. 12 fra 1975 - som må siges at rumme tidsskriftets hidtil eneste længere principielle metodiske diskussion af »real-analysens « grundlags- og udgangspunktsproblemer - søger Kontext-artiklen at fastholde, at et centralt problem i denne teoriforståelse er den tendentielle yderliggørelse af forholdet mellem empiri/historie og de teoretiske kategorier. Denne yderliggørelse er det måske nok vanskeligt at eftervise, al den stund den næppe er direkte tilsigtet, men uanset dens faktiske tilstedeværelse i artiklen er den principielt kritisabel.

Imidlertid kan man sige, at der redaktionspolitisk har været en tendens til en mere restriktiv opfattelse af, hvilke dele af »empirien« der var relevant, med det resultat, at en række problemområder er gledet ud af diskussionen. Problemområder som bl.a. havde med »dagliglivet og dets problemer « at gøre og som ikke begrænsede sig til at se arbejdskraftreproduktion alene som et moment i kapitalreproduktionen og statspolitikken.

I forbindelse med en diskussion af »marxismens krise « skal man nok ikke overse dens sammenhæng med »marxisternes krise«. De tendenser til opbrud og de fors $\varnothing \mathrm{g}$ på nyorientering, som vi her har diskuteret på teoriens område, genfindes jo på de fleste andre områder, politiskorganisatorisk, »privat«, arbejdsmæssigt, osv. Men som et relativt »generations«-specifikt fænomen. Den såkaldte 68-generation, som det jo drejer sig om, er nu så gammel, at den er begyndt at skue tilbage på sin egen historie, udgive memoierer, beklage sig over ungdommen, osv. Vi ser det som noget positivt, at den marxistiske teori således er integreret i forsøgene på at komme til klarhed over mål og midler i tilværelsen, at marxismen er et personligt anliggende, men vi skal nok være mere opmærksomme på ikke at overdrive vor beskæftigelse med os selv. Marxismens udvikling og den hermed forbundne erkendelse må ikke blive en enkelt »generations« privilegium.

4. Problemet med at identificere hvad »kapitallogik« som teoretisk retning er for noget, skal ikke diskuteres her. Det skal blot understreges, at en afgrænsning af en »teoretisk tendens « der udvikler sig, både har dimensioner i tid og rum.

5. Mortensen m.fl., Affirmation eller Emancipation, Kontext 36/37, 1979, især s. 38-70. 
Det fænomen vi upræcist har betegnet »marxismens krise« og som er del af den aktuelle kapitalismekritiks problem, hænger også sammen med teoriudviklingens tilknytning til en universitær sammenhæng og i bredere forstand til åndsarbejderlaget inden for gruppen af statslige lønarbejdere. Opkomsten af dette forhold skriver sig ind i den samfundsmæssige udvikling overhovedet igennem det sidste konjunkturforløb, hvor det danske samfund undergår en dybtgående strukturel ændring som det immanente resultat af kapitalens historiske udfoldelse.

Nu kan den »krise « eller de problemer, som den teoretiske kritik af kapitalismen står over for, jo ikke kun være begrundet i en manglende refleksion af hvilke som helst aspekter af samfundet og lønarbejdernes eksistens. Resultatet af et sådant synspunkt ville være den i princippet uendelige petitesseforskning. Marxismens problem må langt mere centralt begrundes i forhold til den samfundsmæssige udvikling. Dvs. formår kapitalismekritikken at holde sig på højde med de problemer og modsætninger, som aktualiseres gennem den samfundsmæssige udvikling selv? Men hvad er det for forhold denne udvikling har sat i centrum, når focus er sat på arbejdskraftens reproduktion?

Der er sket en almengørelse af lønarbejdet, idet en stadig stigende del af befolkningen henvises til lønarbejdet som deres eneste eksistensmulighed. I forhold til den til enhver tid givne klasse af lønarbejdere kan man endvidere tale om to dimensioner i denne almengørelse. En ekstern, dvs. udbredelsen af lønarbejdet til nye befolkningsgrupper, således som det har været tilfældet ved den absolutte overflødiggørelse af landbrugets arbejdskraft gennem dettes fortsatte kapitalisering. Og en intern, dvs. en udbredelse af lønarbejdet inden for klassen af lønarbejdere $\mathrm{i}$ alt overvejende grad gennem en kraftig forøgelse af kvinders lønarbejde.

Almengørelsen af lønarbejdet er ledsaget af en omstrukturering af det samfundsmæssige arbejdskraftforbrug indenfor og mellem kapitalens produktionsog cirkulationssfære samt staten, og har betydet en række forandringer gående fra nye geografiske lokaliseringer til ændrede kvalifikationsstrukturer.

Statens vækst føjer sig ind i denne sammenhæng i to dimensioner. På den ene side ved, at almengørelsen og omstruktureringen af lønarbejdet og lønarbejderklassen i vidt omfang temporært og vedvarende formidles gennem en udbygning af den statslige intervention i arbejdskraftens reproduktion. På den anden side gennem et stærkt forøget statsligt arbejdskraftforbrug til varetagelse af denne intervention. ${ }^{6}$ Der er således frembragt en kvantitativ større (absolut og relativt) klasse af lønarbejdere

6. Endnu et aspekt ved den statslige socialpolitik kan fremhæves, nemlig dens indholdsmæssige kontrol eller repression med lønarbejdernes levevis. Risto Eräsaari argumenterer i sin artikel for nødvendigheden af at udvikle statskritikken på dette område og Finn Hansson diskuterer kontrolbegrebets placering i socialpolitik- og reformismediskussionen $\mathrm{i}$ »selvhjælpsorganisering i arbejderklassen ...« 
med en kvalitativ ny sammensætning og kvalitativt anderledes eksistensbetingelser. Denne omstrukturering er udfoldet gennem kapitalakkumulationens cykliske forløb og markerer derfor dette som en historisk fremadskridende proces. Den nuværende krise er således på en gang udtryk for en gentagelse (udfoldelsen af kapitalakkumulationens immanente modsætninger) og samtidig en historisk videreudvikling af kapitalismen og dermed af lønarbejderklassen.

I det foreliggende nummer af Kurasje har vi hovedsageligt fokuseret på reproduktions- og statssiden i denne udvikling med den begrundelse, at lønarbejdernes ændrede samfundsmæssige situation og krisens gennemslag finder udtryk og formidles her, hvilket bl.a. viser sig i lønarbejdernes interesseartikulering og -kampe.

Historisk er reproduktionskampens udvikling karakteriseret ved dels en udbredelse af traditionelle former til nye områder (de statslige lønarbejderes faglige aktivitet) dels udviklingen af nye former (løst sammenfattet i termen: »bevægelser «), der umiddelbart udgør et brud med de historisk etablerede sammenhænge som interesserne artikuleres i (fagforening, parti). Samtidig kan man dog registrere parallelle ansatser både i de nye og etablerede former til at reflektere lønarbejdereksistensen i sin totalitet i højere grad end det har været tilfældet tidligere.

Disse forskydninger og brud i lønarbejdernes samfundsmæssige artikulationsformer er enten umiddelbart fremkaldt af krisen og dens formidlede gennemslag i staten og de statslige reproduktionspolitikker, eller de får deres problemfelt forstærket af krisen. For så vidt krisen imidlertid ikke blot peger på en demontering af disse eksistensbetingelser som en simpel reversibel bevægelse, bliver det samtidigt påtrængende at få begreb om, hvad det er for langsigtede historiske tendenser, der kommer til udtryk i de ændrede interesseartikuleringsformer.

Umiddelbart fremtræder de som begrundet $\mathrm{i}$ vidt forskellige forhold og synes kun at have den ene fælles identitet at bryde med hidtidige artikulationsformer; deres sammenføjning går stadig over og er fastholdt i det borgerlige samfunds objektive strukturer og er derfor tvangsmæssigt reformistiske. De markerer snarere reformismens tilpasning til ændrede samfundsmæssige betingelser end et brud med reformismen. ${ }^{7}$

7. I forhold til ovenstående repræsenterer A. Wacker's artikel en 'gammel' diskussion, men han fors $\emptyset$ ger et opgør med alt for firkantede forestillinger om massearbejdsløshedens politiserende effekter. Bjarne Andersson/Steffen Kiselberg forsøger i deres artikel at pejle sig ind på de forandringer i den mandlige lønarbejders personlighedsstruktur, som fremtvinges af ændringerne i den kønslige arbejdsdeling.

Finn Hansson/Peder Lærke Nielsen forsøger at sammenfatte nogle hovedtræk omkring den statslige institutionsudbygning som led i reproduktionsstrukturens udvikling med perspektiv på reformismediskussionen.

U. Schmiederer sammenfatter udviklingen i den nyere reformismediskussion og fors $\emptyset$ ger at indkredse nye momenter og modsigelser omkring dannelsen af klassebevidstheden. 
En nærmere diskussion og analyse af de nye reaktionsformer på krisen - 'bevægelserne' - havde det været nærliggende at gå ind på her, men det har ikke været muligt for os til dette nummer. Men det er alligevel vigtigt, at få startet diskussionen om hvordan vi kan analysere de her skitserede problemområder, »dagliglivet«, som momenter i det nuværende kapitalistiske samfunds reproduktionsprocesser.

Diskussionen af disse metodiske principper kan (foreløbig) deles i to men ikke gensidigt udelukkende dimensioner:

a) teoriudvikling med udgangspunkt $i$ en lokalisering af nogle nye træk ved dele af det kapitalistiske samfunds reproduktionsprocesser - en lokalisering hvis reflektion dernæst forfølges i den marxistiske teoridiskussion. ${ }^{8}$

Med udgangspunkt i forandringer i arbejderklassens reproduktionsbetingelser kan der rejses problemstillinger og spørgsmål til analyser og bestemmelser i den aktuelle reformismediskussion. Gennem at pege på den fraværende diskussion af de forandrede reproduktionsbetingelser og deres betydning for arbejderklassens reproduktionskamp kan kritikken af reformismediskussionen tematisere centrale problemstillinger for den videre teoriudvikling. Det er dog et problem ved denne fremgangsmåde, at den vanskeligt kan opstille nogle kriterier for den historiske analyse, der danner udgangspunktet for den teoretiske diskussion. Dette er imidlertid det umiddelbare udgangspunkt for

b) hvor videnskabskritikken og den historiske analyse er sammenkædet. Igennem et opg ør med ideologiske forståelser af den borgerlige videnskab fastholdes en påvisning af dens samfundsmæssige bestemmelser i forholdet til kapital og stat, ${ }^{9}$ hvor klassebestemmelsen af åndsarbejderen indtager en central plads. Problemerne, der er forbundet med den historiske analyse og udvikling af kategorierne i kritikken af den politiske økonomi, formuleres her inden for rammerne af en systematisk kritik af det borgerlige samfunds egne reale reflektionsformer, videnskaben. Kritikken af den borgerlige videnskab bliver på denne måde en del af svaret på videreudviklingen af den marxistiske

8. Dette svarer til de metodiske hovedlinier hos Hansson og Lærke Nielsen, hvor udgangspunktet er forandringer i arbejdskraftens reproduktionsstruktur, forandringer der begrebsligt forfølges gennem diskussionen af den nyere marxistiske reformismediskussion.

9. Forskellen mellem Kurt Aagaard Nielsen og Finn Dam Rasmussens tilgang til diskussionen af videnskabskritikken er kort, at førstnævnte tager udgangspunkt i den marxistiske teoridiskussions forankring blandt statsansatte intellektuelle og derfra udvikler argumentationen for en systematisk kritik af den borgerlige videnskabs kapitalaffirmativitet, mens Finn Dam Rasmussen spørger om det teoretiske arbejde og den revolutionære teoris betydning og dernæst diskuterer dens udviklingsbetingelser. Begge ser imidlertid kritikken af den borgerlige videnskab - de borgerlige tankeformer - som grundlaget for lokaliseringen af historiske forandringer i kapitalforholdet og dets reproduktionsbetingelser. 
teori, selv om problemerne med at etablere sammenhæng mellem den borgerlige videnskabs parcellerede og opsplittede karakter og marxismens totalitetsforståelse endnu er uløst.

Hvis diskussionerne af »dagliglivet« skal fastholde et udgangspunkt i kritikken af den politiske $\varnothing$ konomi dukker en række nye problemstillinger op. Vi har ingen forestillinger om, at vi i dette nummer af Kurasje kan nå at dække alle områder, og selv om vi anser de her skitserede dimensioner og problemfelter for centrale, er der stadig »huller « eller udækkede områder. På den anden side påstår vi heller ikke at udviklingen i det daglige livs former er de eneste betydningsfulde forandring i den seneste akkumulationsfase, men disse forandringer i de klasse- og kønsspecifikke reproduktionssammenhænge indtager en dominerende plads.

Til de udækkede områder hører, at vi går helt uden om diskussionen af forandringer i socialisationen af lønarbejderen, selvom vi nok diskuterer ændringer i de forhold, der indvirker på denne. Ligeledes går vi uden om diskussionen af eksistensbetingelserne (udbytningsbetingelserne) i den umiddelbare produktionsproces, hvor vi dog alment diskuterer de metodiske problemer, som er forbundet med sådanne analyser.

Et andet af de vigtige problemområder vi heller ikke tager så meget fat på er udviklingsprocesserne for de sociale bevægelser, ${ }^{10}$ kvindebevægelser, beboerbevægelser, energibevægelser osv. Ligeledes er det vigtigt at disse sociale bevægelsers struktur og funktion samt deres forhold til den etablerede partipolitiske struktur analyseres. Men alle disse bevægelser har baggrund i forandringer i reproduktionsbetingelser og reproduktionsstruktur, forandringer som peger på ændrede former for sociale problemer. Og som antyder, at væsentlige problemdele ikke kan artikuleres gennem arbejderklassens traditionelle organisationsformer for reproduktionskampen.

$\mathrm{Nu}$ er arbejderklassens kamp for et befriet dagligliv dens egen sag, men de p.t. mere privilegerede lag af klassen indgår i denne kamp med egne legitime krav på socialismen. Kort sagt er det vi lønarbejdere skal befri vores egne indbyrdes forhold i dagligdagen, og det vi skal befri os fra, er den kapitalistiske udformning af denne dagligdag. Eller som Marx siger: de elementer af det nye samfund, der har udviklet sig i skødet på det gamle kapitalistiske samfund, må sættes fri.

Det er i denne sammenhæng, at reproduktionskampdiskussionen - som element i en kritik af »det daglige liv« - må vurderes og prioriteres. Det er altså

10. Ali Wacker går i sin artikel i dette nummer eksemplarisk også tilbage til krisen i 30'erne, for at påvise at den automatiske sammenbrudsteori i høj grad blokerer marxister for at forholde sig til den aktuelle kriseudvikling. 
gennem kritikken af de kapitalistiske samfundsmæssiggørelsesformer, at alternativet til den kapitalistiske dagligdag og dens relationer mellem f.eks. kønnene, generationerne, mellem arbejde og »fritid« overhovedet kan konkretiseres.

Bjarne Andersson

Finn Hansson

Peder Lærke Nielsen

Finn Dam Rasmussen

\section{STATEN I DET KAPITALISTISKE SAMFUND - EN INTRODUKTION. Genoptryk af artikler fra Kurasje. 72 sider, 25,- kr.}

I den diskussion af staten i det kapitalistiske samfund, som startede i Danmark i begyndelsen af 70'erne, indtog Elmar Altvaters artikel »Om nogle problemer ved statsinterventionismen « en central plads. I diskussionens forløb overså mange, både »tilhængere « og »modstandere «, hvad artiklens centrale problemstilling var. Når man dengang lagde hovedvægten på Altvaters forsøg på at bestemme centrale statsfunktioner, overså man, at artiklen primært er en kritik af den keynesianske blandings økonomi - af denne $\varnothing$ konomiske politiks grænser og dens midlers binding til cirkulatonssfæren. Ligeledes påviser artiklen hvorledes de borgerlige $\emptyset$ konomer og "politikmagere « er fikseret i disse sammenhænge og ikke kan begribe de egentlige akkumulationsproblemer for kapitalen.

Og disse kritikpunkter kan næppe siges at være blevet gjort overflødige. De sidste 5 års krise og desperate statslige løsningsfors $\varnothing \mathrm{g}$ har tværtimod gjort det endnu mere nødvendigt for socialister at fastholde en konsekvent kritik af de statslige kriseløsninger - lige meget hvorfra de så kommer!

I den forstand er artiklerne i denne bog lige så aktuelle som da de første gang udkom og er stadig de bedste introduktioner til statsdiskussionen. 